\title{
A Formação Ético-Humanística do Estudante de Medicina como Estratégia para a Prevenção de Erros Médicos
}

\author{
Rodrigues, Fillipe Ferreira; Duarte, Josiane Aparecida; Oliveira, Bruna Miclos de; \\ Gonçalves, Suziane Soares; Dantas, Letícia Lopes; Paz, Fabrício Nunes da; Dias, \\ Danilo Borges
}

Universidade Católica de Brasília — fillipefrod@gmail.com

Introd:Quando se diz respeito à formação médica de qualidade, não se pode deixar de levar em consideração a temática da formação humanística em saúde.O atual modelo de educação médica, muitas vezes focado em métodos que se limitam às ferramentas de desenvolvimento científico e tecnológico, não atende às atuais expectativas e demandas da assistência em saúde.Sendo assim, ganha propriedade o argumento que valoriza a importância da formação do caráter ético e humanístico dos profissionais, afim de atenuar os possíveis erros médicos, bem como otimizar a atenção em saúde nos seus mais diversos níveis.Objet:Expor a temática do erro médico e discutir sobre os benefícios da prática médica em comunidade para a formação ética e humanística do futuro profissional de saúde.Métod: o presente trabalho foi confeccionado com base em pesquisa bibliográfica e relatos de experiências vividas por estudantes de medicina durante trabalhos de extensão universitária.Result: Diz o artigo 29 do Código de Ética Médica:"é vedado ao médico praticar atos profissionais danosos ao paciente, que possam ser caracterizados como imperícia, imprudência ou negligência."Grande parte dos erros médicos são causados por negligência,as quais são falhas que não residem na falta de conhecimento científico, mas sim, na falta de ética ou incapacidade de se estabelecer um diálogo adequado entre médico e paciente. Porém,deve-se destacar que tal habilidade é desenvolvida a partir de práticas e experiências que nem sempre são oferecidas durante a graduação.O trabalho de extensão universitária,aqui referido,objetiva promover educação em saúde a uma comunidade carente situada em zona periférica de Brasília.A mesma possui características peculiares, sobretudo por ter se constituído como fruto da discriminação,no passado,de portadores de HIV e seus familiares. a atividade tornou-se importante fonte de aprendizado e experiência para os voluntários, sobretudo no que diz respeito à construção do caráter ético e humanístico médico.Primeiro por permitir $o$ desenvolvimento de valores como solidariedade $\mathrm{e}$ acolhimento.Em seguida,por permitir o amadurecimento e desenvolvimento do diálogo com o paciente,além de possibilitar a compreensãode seu contexto de inserção social.Trata-se de uma estratégia que estimula a autonomia dos acadêmicos eo respeito à diversidade cultural e moral,elementos fundamentais para a formação do caráter,indispensáveis ao desenvolvimento de habilidades de controle da vida e à manipulação do semelhante como atributo central da prática médica.Concl:Estas experiências resultam na qualificação da relação médico-paciente, por meio do amadurecimento de parâmetros humanitários, de solidariedade e de cidadania.O constante contato com o paciente é fundamental para fazer surgir e amadurecer o conceito de ética tornando possível a formação integral do profissional de saúde, consolidando seu comprometimento com a prática médica,o que o fará,consequentemente,menos sujeitos ao problema do erro médico.

Rodrigues, Fillipe Ferreira; Duarte, Josiane Aparecida; Oliveira, Bruna Miclos de; Gonçalves, Suziane Soares; Dantas, Letícia Lopes; Paz, Fabrício Nunes da; Dias, Danilo Borges. A Formação ÉticoHumanística do Estudante de Medicina como Estratégia para a Prevenção de Erros Médicos. In: Anais do Congresso Internacional de Humanidades \& Humanização em Saúde [= Blucher Medical Proceedings, num.2, vol.1]. São Paulo: Editora Blucher, 2014. ISSN 2357-7282 DOI 10.5151/medpro-cihhs-10780 